Socialist Studies / Études socialistes Volume 9 (1), Spring 2013

Copyright $\odot 2013$ The Author(s)

Article

\title{
SEEDS OF RESISTANCE: TOWARDS A REVOLUTIONARY CRITICAL ECOPEDAGOGY ${ }^{[1]}$
}

\author{
PETER MCLAREN \\ University of California, Los Angeles, United States and \\ Chapman University, Orange, United States
}

\begin{abstract}
The death throes of mother earth are imminent unless we decelerate the planetary ecological crisis. Critical educators, who have addressed with firm commitment topics of race, class, gender, sexuality, disability, and other social justice issues are casting their eyes to the antagonism between capitalism and nature to ask themselves how we can rationally regulate the human metabolic relation with nature. As the global power complex reduces human life and mother earth to mere production and consumption, critical revolutionary ecopedagogy is developing new, unalienated forms of selfpresence. Ecopedagogy is inspired by and inspires a new social arc, rooted in practices of ecological struggles by the working classes and the poor - an unabashedly utopian dreaming of a post-capitalist future.
\end{abstract}

\section{Keywords}

Capitalism, ecocide, ecopedagogy, imperialism, revolution

Our mother earth is convulsing, choking on the filth, the dye, the pesticides, the toxins, the effulgent splendour of chemicals and the dread unleashed by the furnaces of human greed. Her death throes are imminent unless we decelerate the planetary ecological crisis. Critical educators, who have addressed with firm commitment topics of race, class, gender, sexuality, disability, and other social justice issues are casting their eyes to the antagonism between capitalism and nature to ask themselves how we can rationally regulate the human metabolic relation with nature. As the global power complex reduces human life and mother earth to mere production and consumption, critical revolutionary ecopedagogy is developing new, unalienated forms of selfpresence. Ecopedagogy is inspired by and inspires a new social arc, rooted in practices of ecological struggles by the working classes and the poor - an unabashedly utopian dreaming of a post-capitalist future. 


\section{Geographies of Ecocide}

The crises of global capitalism, including grotesque inequalities and ecocide, are not self-standing - they form an organic unity. In capitalist societies such as ours, selfalienating subjectivity is always already social alienation linked to the social relations of production, to racialized and gendered antagonisms, and to the normative constraints of what Best, Kahn, McLaren and Nocella (2011) refer to as "the global power complex" that reduces everything to production and consumption. It is this alienation that generates the self which remains isolated from its Other, including the natural world. Living within the state of planetary eco-crisis so aptly characterized by Richard Kahn (2010) as constituting 'geographies of genocide, ecocide, and zoöcide'1 we cannot experience our self-presence except through the anamorphically distorting mirror of capital.

Now that Keynesian stimulus measures no longer suffice to resolve the structural crisis of capitalism, and now that the frontiers of cheap resources are closing down, we are witnessing the dynamic increase in asset-stripping capitalism. Financial channels are used to plunder and pillage, as profit-making is linked to the fastest and largest rates of return inextricably tied to the world of fictitious commodities that dilapidate the sources of past revolutions of productivity. For instance, the agro-food transnationals seek to capture profits through price inflation rather than through advances in productivity. Petty commodity producers saw their profits drop as finance capital subordinated all commodity logic to the competitive logic of global financial markets. In other words, finance capital makes all parts of the world ecology commensurable with one anotherreducing the natural world and everything in it to generic income streams, as surplus value that can be extracted in the absence of a revolution in productivity.

\section{Asset Capitalism and Imperialism}

Asset capitalism and the juggernaut of imperialism that follows in its wake has the potential to wreak further havoc upon the world in terms of imperialist wars, as well as the ecological destruction of the entire planet. Sociologist William I. Robinson (2008) has discussed the development of a new transnational model of accumulation in which transnational fractions of capital have become dominant. New mechanisms of accumulation, leading to the dramatic expansion of capital, as Robinson notes, include a cheapening of labour and the growth of flexible, deregulated and de-unionized labour, where women experience super-exploitation in relation to men; the creation of a global

\footnotetext{
${ }^{1}$ To this list, we might add epistemecide, the wholesale 'disappearance' of indigenous knowledges and practices by the guardians of Eurocentric knowledge production, which Kahn subsumes under the term zoöcide.
} 
and regulatory structure to facilitate the emerging global circuits of accumulation; and neo-liberal structural adjustment programs which seek to create the conditions for unfettered operations of emerging transnational capital across borders and between countries.

Financial oligarchies like the corporate elite, and their allies in the corridors of United States political power, benefit from the consolidation of numerous matrices of power, whose generation of surplus value potential is transnational in reach, and whose multifarious and decentralized institutional arrangements are organized around the industrial, bureaucratic and commodity models associated with the military industrial complex. All of these 'power complexes' have intersecting social, cultural and political spheres that can be managed ideologically by means of powerful, all-encompassing corporate media apparatuses and the culture industry in general, including both popular and more traditional forms of religious dogma and practice. Assuming a position of major importance today is the religious industrial complex that provides the moral alibi for acts of war and military incursions throughout the world, so necessary for imperialist expansion.

We are witnessing the profound dismantling of national economies and the reorganization and reconstitution of national economies as component elements or segments of a larger global production and financial system. As Robinson observes, there is a decentralization and fragmentation of the actual national production process all over the globe while the control of these processes, these endless chains of accumulation, is concentrated and centralized at a global level by a transnationalist capitalist class. All of these power complexes overlap and interpenetrate each other at the level of capital accumulation and value production. At the same time, the sovereign ideologies of the capitalist state are reinforced through both new and old media technologies, resulting in an imperfect but nontetheless over-determined ideological climate that enables major 'class' conflicts to be avoided.

Grosfoguel (2007, 2007a, 2008, 2008a) reminds us that this power complex has an ignominious history. The rise to power of Reagan and Thatcher is often traduced for being the midwife to neoliberal capitalism, but the horror of accumulation by dispossession was well established long before their violent attacks on miners and air traffic controllers. In 1492, it was not just economic colonization that visited las Americas, but multiple antagonisms. This included a global class formation where a diversity of forms of labour coexisted, including slavery, semi-serfdom, wage labour, petty-commodity production, and so on. These diverse forms of labour, organized by capital, became a source of production of surplus value through the selling of commodities for a profit in the world market. Simultaneously, an international division of labour between core and periphery emerged, where capital organized labour in the periphery around coerced and authoritarian forms. At the same time, an interstate system of politico-military organizations controlled by European males and institutionalized in 
colonial administrations supported a global racial/ethnic hierarchy that privileged European people over non-European people. This was organically intertwined with a global gender hierarchy that privileged males over females and the system of European patriarchy over other forms of gender relations, alongside a sexual hierarchy that privileged heterosexuals over gays and lesbians. A spiritual hierarchy privileged Christians over non-Christian/non-Western spiritualities, institutionalized in the globalization of institutionalized Christianity, while an epistemic hierarchy upheld Western cosmology and systems of intelligibility over non-Western knowledge and cosmologies, institutionalized in the global university system, complemented by linguistic hierarchy between European languages and non-European languages that privileged Eurocentric knowledge as true communication and rational knowledge/theoretical production yet denigrated indigenous knowledges as 'merely' folkloric or cultural and not worthy of being called theoretical.

The consequences of the simultaneous emergence of a transnational forms of capitalism based on the exploitation of human labour and the endemic crisis of capitalism - based on the political, class conflicts taking place given exploitative relations of productions - is also the origins of the current ecological crisis. In the same ways that the exploitation of human labour sustains the conditions of possibility of all other antagonisms, including profound, globalized racial hatreds, which is not to reduce them all to class, transnational forms of capitalism today and their historical precedents are preconditions for ecocide.

\section{Capitalist Ideology and Capitalist Discipline}

The preconditions for exploitation, alienation and ecocide are not only material, although of course there are also that, but ideological. The global power complexes tacitly and manifestly teach values, and produce ideational schemata that serve as interpretive templates or systems of intelligibility through which the popular majorities make sense of everyday life via the language of technification, corporatization, bureaucratic administration, and commodification knitted together (in the United States) by ideological imperatives of religious ideology, American exceptionalism, and the coloniality of power. The ecological devastation of the planet must be understood as partly a product of the ideologies and discipline of capitalist imperialism.

Insinuating itself into our daily life as an ideology as much as a set of accumulation practices and processes of production, neoliberal capitalism pretends moreover to the throne of democracy-building but in reality it has hastened its demise. Capitalism wears a coquettish and self-effacing sheen of timelessness, inviolate consistency, and seamless immutability, but that sheen is not any more permanent than the lipstick worn by a cloak room attendant in a men's club. What makes capitalism seem 
indelible yet imitable is the fact that it makes certain people very very rich, and these paragons of the capitalist class are those that the state and corporate media apparatuses parade in its garish media outlets - the movie stars, the corporate moguls, the trendsetters, the celebrities and the culture brokers. Not only do they control the culture industry, they are lionized for it. While news of celebrity cellulite in the gossip columns of Hollywood barons shakes us awake with amphetamine alertness, we remain emotionally drowsy to the pain and suffering of people who struggle and strain against falling household wealth, unemployment and lack of food and medical care. We are inured to the catastrophic suffering of mother earth.

In the meantime, capitalist discipline, "that which people do to prepare themselves for exchange on the money economy" (Fassbinder 2008), binds the self to a lifetime of alienated, capitalist labor. The social relations of production, then divide people into a class of owners who control the money economy by manipulating exchange for the sake of capital accumulation, and a class of people-commodities whose lives are dedicated to preparing themselves to sell their labour-power to capital. Everyone outside of the owning class is at least a potential member of this second class -- see e.g. Marx (1967: I) on the "industrial reserve army," which, as Marx said, "belongs to capital just as absolutely as if the latter had bred it at its own cost" (Marx 1967: I, p. 784). Under capitalism we of the working class must continually (re)commodify ourselves in order to survive regardless of the odds of actual survival. Needless to say, this commodification of the self is simultaneously an alienation from the Other and from the natural world.

\section{From Pedagogy to Ecopedagogy}

Despite the long-standing threat of capitalism to planetary survival and the more recent intensification of that threat through transnational forms of asset capitalism, environmental questions were largely undiscussed in recent decades. In the 1980s and 1990s, as a result of the unrelenting onslaught of consumer culture and progressive education's overweening emphasis on identity politics as a solution to creating a more vibrant and critical public sphere, issues of environmental sustainablity maintained but a lifeless presence, including within critical pedagogy. Now, in the early 2000s, motivated by the sustainability crisis and emboldened by the courageous activities of various planetary social movements, ecopedagogues have arrived on the scene and not only developed a powerful argument about how to respond to the crises of sustainability, but also offer a very timely and important contribution to critical pedagogy and community action at a time of resource shortages, climate change, economic instability and ecological breakdown.

Richard Kahn (2010) emphasizes that pedagogy has evolved consciously to become ecopedagogy as a planetary universal state of community-based emancipatory 
education. Critical educators are joining a politically reinvigorated youth, who are beginning to refuse the cult of individualism as an antidote to their loss of a sense of self. They no longer accept being situated as impersonal agents in a rationalized society that is highly competitive and achievement and psychotherapeutically-oriented. And while they are taught to concentrate on their personal status and well-being, they know that they and their loved ones are not assured of protection from misery and oblivion.

The 2011 student mobilization in Chile, the activism of Nigerian youth at the Niger Delta crude oil flow station, the clench-fist protests against the ruling establishments of Tunisia, Egypt, and Libya, the resistance to the austerity measures by the youth in Portugal, Spain, and especially Greece, the South African public students who struggle to secure basic teaching amenities, such as libraries, in their schools, the Occupy Wall Street movement in the United States -- all of these are part of a growing culture of contestation. Of course, 'Occupy' means something else to indigenous peoples who have long fought imperial occupation. Nonetheless, the Occupy movement was courageous insofar as it put questions of inequality and ecologically sustainability on the map for European/settler populations.

Many of these movements self-consciously resist capitalism's transnational reach, while insisting that concerns with capitalism and ecology are all of one piece, entangled. For instance, youth in these movements examine how their food is produced in terms of sustainable water and land use, critique the harsh treatment of small-scale farmers, raise the alarm around climate change while outlining the negative implications of global warming for food production and sound the charge against the exploitation of women and immigrant workers in food production and agricultural distribution. Capitalism, as Jason Moore (2011) has articulated, is understood increasingly a a "world-ecology" that connects the accumulation of capital to the exploitation of nature and working class peoples, in a toxic and unholy alliance. New social movements, led by the world's youth, are increasingly insisting upon this connection.

\section{Towards Revolutionary Critical Ecopedagogy}

I am using the term revolutionary critical ecopedagogy in a special sense as a reconfiguring force of socialism. I specify this because the term "revolution"has become domesticated in consumer culture and I don't want to replicate the hegemonic, if ludicrous, conception of this insurgent process in such a away that confuses it with some new 'revolutionary' version of a laundry detergent. Some would argue that ecopedagogy is already revolutionary and critical and should simply be denoted as "ecopedagogy." But the term revolutionary critical pedagogy draws attention to my conception of ecopedagogy as denoting a transformation of capitalism to a democratic socialist alternative, that is, a tranformation of institutions of power on behalf of social justice. In 
this view, any state that fails to provide food, home, education, shelter and medical assistance to its populace is considered "unnatural" and should not be left to die out but should be overturned and a new regime replanted in the soil of the old. At the same time, this socialist challenge is at once an ecological challenge. In the words of John Bellamy Foster (2009, p. 34):

The socialist goal of transcending the alienation of humanity is impossible to achieve to any considerable extent unless it coexists with the goal of transcending the alienation of nature. Likewise, the ecological goal of transcending natural alienation is impossible to attain without addressing social alienation. Socialism is ecological, ecologism is socialist or neither can truly exist.

With contributions from authors and activists such as Richard Kahn, Tina Evans, David Greenwood, Samuel Fassbinder, Antonia Darder, Sandy Grande and Donna Houston (to name just a few) the field of critical, revolutionary ecopedagogy is now on a potent trajectory. Bringing their contributions into conversation with the efforts of Vandana Shiva, Joan Martinez-Alier, Joel Kovel, Jason W. Moore and John Bellamy Foster has cultivated a landscape of important transnational planetary ecopedagogy rooted in worldwide activism. We are now witnessing a profound demonstration of an efficient integration of the social, educational and ecological justice movements. In opposition to capitalist discipline, as it contributes to the ongoing crisis, ecopedagogic practices can be organized into a sort of "ecological discipline" (Fassbinder 2008), binding people to the defense of diversities both ecosystemic and social against capital's manipulation of them as people-commodities.

In this sense, recent books such as Critical Pedagogy, Ecoliteracy, and Planetary Crisis: The Ecopedagogy Movement (Kahn 2010), Occupy Education (Evans 2012) and Greening the Academy (Fassbinder, Nocella and Kahn 2012) very much constitute a critical revolutionary pedagogy of convergence and integration bound together by ecological discipline. The work of European sustainability scholars and activists is brought into dialogue with powerful emergent voices from las Americas. These approaches interrogate the rust-splotched and steampunk metropolises and tumbleweed hinterlands of neo-liberal capitalism and work towards a vision of what a world outside of the menacing disciplines of neo-liberal capitalism might look like.

For instance, Tina Evans' (2012) work is built upon in-depth theories about the nature and purposes of sustainability. Yet, Evans is acutely aware that the politics of sustainability is not a pitch-perfect love story and can easily be co-opted by the guardians of the state. These guardians make empty promises to manage the crisis in the interests of the so-called public good, but really in the interests of private greed. Thus, discourses of sustainability can be hijacked by the very interests that Evans is out to unmask. As Josee 
Johnston points out, for example, in "Who Cares About The Commons?", "sustainability has come to imply sustainable profits as much as 'saving the earth"” (p. 1). Indeed, as Kahn (2012) argues in his introduction to Greening the Academy, the academy itself is managing sustainability for private greed in exactly this way - and this despite the fact that its own knowledge workers document the catastrophic conditions ecological conditions that we have created and that we now face.

Understanding how such hijacking takes place and how the imperial instinct remains alive and well even among some progressive educators is a major task. Evans answer is to anchor 'sustainability' in place-based theory and action, rooted in multiple contexts of practical lived experience - experience that has been inestimably impacted by neo-liberal capitalist globalization and sustained opposition to it. In this context, the starting point for a meaningful understanding of sustainablity is the sufferings of the planetary oppressed.

In developing this theory and practice, the decolonial school may be of brilliant assistance. Decolonial scholars have charted out the conflictual terrain known as the 'coloniality of power' (patrón de poder colonial), and 'the Eurocentric pattern of colonial/capitalist power' (el eurocentramiento del patrón colonial/capitalista de poder). Ramón Grosfoguel, Anibal Quijano, Linda Smith, Enrique Dussel, Sandy Grande and others call for what Kahn refers to as a 'revitalized ecology of body/mind/spirit', alongside an emphasis on 'planetarity' in the praxis of ecopedagogical struggles, struggles which seek to achieve specific, cumulative goals. Thus, for instance, Grosfoguel, Quijano, Dussel, and other 'decolonial' thinkers emphasize the 'global ecology' of capitalism, as a series of dependent hierarchies implicating specific forms of spirituality, epistemology, juriprudence and governance, patriarchy and imperialism. As Richard Kahn (2012) argues, this affinity betweeen Evans' work and the decolonial school suggests possibilities for the development of a 'counterhegemonic bloc of ideological alliance' among environmental educators, indigenous scholars, non-academic knowledge workers, and political activists of various and sundry stripe - or what Kahn in his own path-breaking work has called 'the ecopedagogy movement'.

\section{Ecopedagogy in Dialogue with Marx}

My own approach to revolutionary critical pedagogy and revolutionary critical eco-pedagogy is not so much theoretically multiperspectival as it is dialectical, emerging from the Marxist humanist tradition and beginning with the works of Marx himself. Marxist educators need to include an ecological dimension in their work: in the discourse of 'asset' or predatory capitalism, is not the exploitation of human labour and endless consumption a logical corollary of the extermination of indigenous peoples? More importantly, "labour" is itself a category within "nature" which, as Marx recognizes, exists 
from capital's perspective as a "free gift." Also Moore (2011), fingers capital as the owner of this perspective. Moore argues not only that "capital externalizes nature through the appropriation of extra-human nature as 'free gift' (Marx 1967 III:745), but also asserts that nature's free gifts are not "limited to minerals, soil, and so forth: they also include human labour power (re)produced outside the circuit of capital (Marx 1967:377)." Thus capital exploits both society and nature in the way ascribed to its exploitation of nature as such. Moore (2011m p. 109) is worth quoting in full on this point:

In privileging labour productivity over land productivity, capital reconfigures the relations between humans and the rest of nature (Marx 1967). Value, Marx argues, internalizes nature through the alienated elevation of human labour power to primacy. Labour power, as abstract social labour (which might be thought of as the average labour time inscribed in the average commodity), becomes the decisive metric of wealth in capitalism. At the same time, capital externalizes nature through the appropriation of extra-human nature as "free gift" (Marx 1967 III:745). Nor are naturee s free gifts limited to minerals, soil, and so forth: they also include human labour power (re)produced outside the circuit of capital (Marx 1976:377-378).

At the same time, environmental activists need to follow Moore's lead (and that of Joel Kovel and John Bellamy Foster) and engage directly with the writings of Marx. No longer can environmentalists continue to rely upon capitalism for solutions to the problems which were caused by the capitalist system: thus Marx's critique of political economy, which helped guide his devastating critique of capitalism, is appropriate to proactive responses to today's environmental crisis. But not only can Marx's work reveal to the educational left how attempts to harmonize revolution and reform not only serve to diminish both, but his work can also be used to find some helpful markers for charting out what a post-capitalist future might look like.

Curry Malott (2013) offers a succinct summary of Marx's work that I believe must be foregrounded in the ecopedagogy debate in so far as that debate is limited, too often, to altering existing capitalist social relations to make way for ecological progress:

In other words, altering exchange-relations, that is, redistributing wealth to workers directly through wage increases, or indirectly through taxation and social programs... (which of course would be a huge victory for labour), leaves production relations intact, and thus the substance of value, abstract labour, unacknowledged and thus unchallenged. In other words.... it is not issues of distribution (i.e. poverty and inequality) that so offends Marx regarding capitalism, partly because they are but mere 
consequences of the alienating nature of the social relations of production within capitalism. In other words, Marx objects to the alienation or selfestrangement of capitalism (i.e. abstract labour, the substance of value) because it excludes the possibility of the full, healthy, normal, culturalsocial development of the human being. Because abstract value represents the substance of capitalism, the only way to transcend the alienation of capitalism is to transcend capitalism itself. Even if markets and private property were abolished and wages were equalized, as suggested above, alienation and dehumanization would continue if the social relations of capitalist production represented by the existence of socially necessary labour time, or the generalized standard separating thinking from doing, persisted. Working toward a post-capitalist society that is humanized might include a critical education against capitalism focused on imagining a world without abstract labour. This is the foundation needed for a world of inclusion, or a world inclusive of humanization and against dehumanization.

As Peter Hudis (2012) formulates it in his path-breaking book, Marx's Concept of the Alternative to Capitalism, when labour is determined by necessity and external expediency ends - that is, when we exist outside the social universe of value production and are no longer defined by material production, and our tribulations as human beings seeking to survive the world of vampire capitalism are no longer measured by labour time - then, and only then, are we able to take the first real steps towards freedom. This is because production and consumption will be based, according to Hudis, 'on the totality of the individual's needs and capacities'. Drawing our attention to Marx's storied phrase, 'From each according to their abilities, to each according to their needs', Hudis corrects those who might interpret this phrase as some kind of a quid pro quo.

Here, we need to understand that Marx is not saying that needs are met only to the extent that they correspond to the expression of a given set of abilities. This is the case because it would mean that human relations are still governed by material production. But the true realm of freedom lies beyond material production. Even when we move from socially necessary labour time to actual labour time, we still are outside of the realm of freedom - entering the realm of freedom only occurs when actual labour time also ceases to serve as a standard measure, and labour serves as an end in itself, as part of an individual's self-activity and self-development. As Hudis makes clear, free development for Marx could not be possible when human activity and products acquire an autonomous power and limits are externally imposed on the range by which individuals can express their natural and acquired talents and abilities. Marx went so far as to stress the elimination of the basis of both modern capitalism and statist 'socialist' alternatives to value production. 
From the point of view of ecopedagogy, the re-centering on needs suggests an important reining in of unsustainable extractive practices. In the shift from consumption to the expression of natural and acquired talents, lies the promise of better ecological stewardship. More specifically, a world-society whose members subscribed to some form of ecological discipline, as taught by ecopedagogy, would shift from value production to sustainable participation in ecosystems. Joel Kovel (2007) calls this activity "ecocentric production" (pp. 234-241).

And Hudis gives us something else to consider. He writes that the subjective development of the individual is, for Marx, a crucial precondition of a truly new society; in fact for Marx it was as significant as such objective factors as the development of the forces of production. Here, he took the position that human subjective activity should never be constrained by the forces of its own making. He went so far as to argue that it is not the means of production that create the new type of man, but rather it is the new human being that will create the means of production. Marx understood that there was no way that progressive political forces could just 'will' a new society into being by a force of the imagination or by interlocking fingers with the capitalists in a toast to avoid the eco-sins of the father. Any new society would have to come into existence imminently from the womb of the old society, with its specific conditions of capitalist production and reproduction and the forces in play that challenge such conditions.

One of the promises of indigenous struggles within the current context, without romanticizing them, is the possibility that indigenous ways of being and knowing can be reimagined for a post-capitalist world. That is, from the existing struggles will come a new society, one that is both ecologically viable partly because human needs are the focus and not endless consumption for an insatiable market.

Why, one might ask, did Marx not specify more about the time frame that societies could use as a reference for when they could expect to achieve certain steps in the progress towards freedom? According to Hudis, Marx 'was cautious about getting ahead of what individuals could or could not achieve in the course of their practical history, precisely because he is wary of imposing any conceptions upon individuals that are independent of their own self-activity'. Marx understood that changes would arise from the nature of new forms of production in a post-capitalist society and, as such, he did not feel the need to advocate new forms of distribution. Marx clearly supported the idea of a non-statist and freely associated form of self-governance that emerged from the Paris Commune. But this was a mediatory stage, in which capitalist social relations had not become fully overcome. He advocated the rule of the proletariat - democratic, inclusive and participatory communities of association - as such rule could work progressively to eliminate the social dominance of capital. While I do not claim the proletariat as the sole subject-agent of revolutionary truth, the revolutionary dictatorship of the proletariat, as articulated by Marx, has much value for us today. In addition, decolonial thinkers such as Grande, Martinez, Shiva and others, suggest to us the 
possibilities for radical self-organization and democratic governance that gets away both from the domination of the state and of capitalist world markets, a direction that Kahn calls "the new science of the multitude."

Marx stressed the development of the forces of production (in part, because he did not live to witness the most destructive power in the forces of production), whereas, as Hudis notes, we are witnessing today the need to limit the destructive power of many of these forces before they overtaken us completely. Time is running out on the effort to save the planet from capital's vicious self-expansionary nature, and this is where the works by new ecopedagogy activists can provide us with a crucial intervention. Their work suggests links to existing work by southern/indigenous thinkers, insofar as it emphasizes a new world view grounded in a recognition of human beings as part of the land and natural world.

\section{Linking Ecopedagogy to Praxis}

The ecopedagogues are able to accomplish so skillfully the charting out of a comprehensive critical pedagogy of sustainability. The characteristic virtues and underlying tenets of such a pedagogy include trenchancy, a commitment to social and economic justice, a challenge to those who are engrossing disproportionate amounts of surplus value that are immiserating the world's peasants and a rage against those liberals who in their blinkered thinking remain at best dodgily critical of capital. To this list I would only add the thought that in order to have a critical pedagogy of any kind, we first need to develop a philosophy of praxis, which requires that we recognize that all philosophy is determined by its dialectical relationship to praxis. And I would emphasize that this relationship between philosophy and praxis is imminently ethical in that it is manifested in a preferential option and thematic priority to be given to the oppressed to present their counter-stories and testimonies of resistance. It is also imminently pedagogical in that it recognizes that the languages and discourses of the oppressed have been domesticated, if not destroyed, by the pedagogical practices of the state (in its role as a client to the owning class) and that new languages of resistance are often coded in the interstices of popular struggles. It is imminently transformative in that it adopts a class position in solidarity with the oppressed and remains united in popular, ideological, racial, gender and cultural struggles.

In other words, eco-pedagogy must join up with existing decolonial struggles, of all kinds, as natural allies in the battles against an unsustainable world capitalism. In this regard we might consider Vandana Shiva's advocacy of the Chipko movement (Mies \& Shiva, 1993) as an ecosocialist struggle for the rights of forest use as well as her advocacy of farmers' rights to seed and land through the organization "Navdanya" (Navdanya Trust). Shiva's general principle of "earth democracy" (2005) is congruent with the idea 
that the foundations of the means of production in land, seed, water (and so on) need to be kept in perpetuity by an arranged social commons (Shiva, 2005, pp. 2-4).

In general, we can regard struggles for a post-capitalist world of ecological discipline as being guided by what Joan Martinez-Alier (2002) called the "environmentalism of the poor," the defense of ecosystems by those who live in and among them. He identifies three distinct types of environmentalism, which I have summarized from Fassbinder (2008, p. 97):

1) The "cult of wilderness," preservationism which "arises from the love of beautiful landscapes and from deeply held values, not from material interests" (p. 2). In this thread Martinez-Alier includes the "deep ecology" movement and the organization "Friends of the Earth."

2) The "gospel of eco-efficiency," connected both to the "sustainable development" and "ecological modernization" movements and to the notion of the "wise use" of resources. Martinez-Alier tells us that "ecological modernization walks on two legs: one economic, eco-taxes and markets in emission permits; two, technological, support for materials and energy-saving changes" (p. 6). This, then, is a reformist movement attaching itself to industrialism, and for it, ecology becomes a managerial science mopping up the ecological degradation after industrialization" ( $\mathrm{p}$. 6). It promotes "eco-efficiency," which "describes a research programme of worldwide relevance on the energy and material throughput in the economy, and on the possibilities of 'delinking' economic growth from its material base" (p. 6).

And most importantly -

3) the "environmentalism of the poor," which has as its main interest "not a sacred reverence for Nature but a material interest in the environment as a source and a requirement for livelihood; not so much a concern with the rights of other species and of future generations of humans as a concern for today's poor humans." This is the "environmental justice" movement, and it is centered around what Martinez-Alier calls "ecological distribution conflicts" (p. 12). Its protagonists are locals whose livelihoods are threatened by environmental impacts.

One problem with the Martinez-Alier position is that it makes it seem as though green ecology or animal liberation are bourgeois movements solely and only. Of course, they can be and have been and quite clearly are dialectically related to that history. But 
total liberation pedagogy and politics is not about bourgeois formulations but about the utopian struggle to overcome the domination of nature in every form of its matrix. That is why, for instance, Kahn and others cannot approve of a speciesist environmental justice struggle as ecopedagogy, nor can they approve of environmental justice being turned into a secular struggle about distribution of resources.

\section{The Arc of Social Dreaming}

As a philosophy of praxis, revolutionary critical pedagogy in the service of ecosustainability will need to remain critical, self-reflexive, ethical and practical. Such a praxis is self-relating, it is immanent, it is an inscription into the order of being, a pulsion towards alterity, and it is also connected to the larger language of multiplicity and the historical traditions that can help guide it. It is an arc of social dreaming, a curvature of the space of the self as it is inscribed in our quotidian being. I emphasize this feature of revolutionary critical methodology, or a set of instructions for effective practice.

We generate truth by searching for it and the search itself becomes part of this truth. We don't select the circumstances in which we live; the conditions that impact our choices have arisen from the past and comprise the objective conditions in which we live and act. But as Zizek notes, we also make our history through our actions that actively create the propositions of our activity - we posit, in other words, the very necessity that determines us (2012, p. 466). This means we are obligated to political mobilization. And it is here that the work of eco-pedagogy and indigenous struggles, the most radical of which consistently empphasize protection of the earth and oceans, serve as an important guide.

On a recent trip to the small mountain town of Cheran, one of the eleven Municipios that are officially devoted to the Purépecha nation, I accompanied some educational activists from Morelia to observe attempts by the townspeople to break away from the Mexican state and function as an autonomous community. One aim of the autonomous movement was to form its own citizen militia to protect the surrounding forests from illegal loggers armed with automatic weapons and who are protected by the feared drug cartels. Here one could see the casualty of capital's awkward brutality and unprecedented repression as not simply a relationship for export but rather a home ground violence that permeates the unequal societies of the earth, sprouting in the soil of value production. At the same time, the struggle of the townspeople speaks to ongoing efforts to defend ecological rights (see Martinez-Alier 2002) from capitalist exploitation linked with the worst forms of terror and violence. This is a lesson for eco-pedagogues, in the form of praxis, of everyday struggle. This is the arc of social dreaming, whether or not it is informed by explicitly revolutionary rhetoric.

In Cherán, Michoacán, where el pueblo Purépecha en rebeldía are in a life-anddeath struggle, I could see the spirit of Paulo Freire at work in the attempts of the people 
to become a self-governing community. Here, Freire's entire pedagogical crasis stands for the God of the Poor against both the exgregiousness and good intentions of the God of the Rich (the God of Violence or the God of Unlimited Progress). The fragrance wafting from Freire's axiological thurible is not cassia or sandlewood, or frankincense and myrrh; rather, it is the sacred sage of the indigenous peoples of Las Americas, signifying unwithholding love and salvific grace. Here Freire's face is hidden behind a signature Zapatista handerchief, his pedagogy of liberation bent on creating the necessary albeit insufficient conditions for a world where the boulevards of the lonely and the despised will no longer be drenched with tears from poor mothers carrying pictures of their daughters, sons, and husbands.

In such moments of struggle, we act not from some divine fiat, but from our own compassion, from our love for our brothers and sisters and non-human animals, from our thirst for justice and from our desire to end such needless suffering in the world. Yet the struggle will not be easy. On this path we are threatened by our own human frailty, by those who would betray us and the principles of revolutionary comunalidad, by those who would use us for their own ends, and by the faux revolutionaries who wish to be part of the struggle without sacrificing their own positions of power and privilege. It is these individuals who will take us down the path of working in 'collabourative partnerships' with statist institutions all to eager to co-opt limited environmental resources, using what Kahn (forthcoming) calls 'public relations alchemy'.

But at the same time, there is another kind of imagining that is crucial to critical pedagogy. Eco-pedagogy carries with it the implicit but powerful lesson that we need to talk about the future and to ignore those who tell us that normative considerations and utopian thinking are inappropriate for revolutionary critical pedagogues. This would be, in Marx's view, a self-refuting statement as 'what will be' is always inscribed within the 'what is'. Marx tells us that all transformation must begin in the crumbling edifices of the old society, cobbled together by the smoldering debris left by the laws of motion of capitalist social relations - or, if you prefer something more messianic, by Benjamin's Angel of History. To talk about different futures is desirable as long as such reflection is grounded in reality. Normative statements about the future are inescapable for any revolutionary. The elements of the future are contained within the very structure of the present. But we need to have more than a vision of the future - we need to be committed to a vision that arcs towards the justice that eludes us under the ironclad thrall of capitalism.

Our return to our humanity requires that we posit a new world outside of the well-worn path of American custodianship, and this is a retroactive process in which our presuppositions occur after the event. There is no metaphysical springboard from which to propel ourselves into the future; rather, we propel ourselves from where we are, from being energized by the truth effect of our own commitment to a praxis of liberation what we may consider a concrete universal - and our full fidelity to such a praxis (Žižek 
\& Milbank, 2009). While we have no original source from which to act (we act from a position of exteriority beyond the totality of social relations) and from which to accept the entreaty of the oppressed, that should not stop us from participating in the struggle to build the world anew. This struggle at once practical and imaginative must be one for a world beyond class but also a world in harmony with the natural world and all life, human and non-human, on it.

\section{Ecopedagogy at a Time of Capitalist Cholera}

The biosphere is disappearing into itself, and it is no coincidence that those of us living in regions of the geopolitical center, in the very locations where the forces of exploitation are most acutely developed, will be able to resist (with the help of the arms race and the war economy) this collapse for a longer duration than those labouring in the peripheral countries.

In this ominous moment of capitalist cholera, I do not know if critical pedagogy will be the outcome and expression of historical necessity, or will it be a contingent force that will be erased by the sands of empty, unproductive time - that is, it is unclear whether critical pedagogy will be the result of the constitution of a deeper historical praxis needed at a future historical moment or is merely the contingent construction of such a praxis. And we must live with this realization, as difficult as it might be, that we cannot know the outcomes of our actions and teaching, whether they will be futile or whethr they will be part of the struggles that bring into being a new world out of the current world of suffering, exploitation and greed. We have no choice but to live with this uncertainty. Moreover, given the stakes of a dying earth, we have no choice but to engage in revolutionary struggle.

Standing polemically against and serving as a crucial antipode to the narcissistic individualism of the consumer citizen - to a society founded on the commodity form is revolutionary critical pedagogy. Critical pedagogy seeks those spaces where production is not wholly capitalist, and where new subjectivities can be given birth, subjects unsparingly reflective enough to remain at odds with the consumer subject. The consumer subject, skulking behind the facade of representative democracy, remains bereft of how self-knowledge is tied to the fetishism of the commodity, of how life becomes lumbered with subjectivities that are monomaniacal, ungrateful, intellectually insecure, which are given to Trump-style fantasist ravings, which are at sea in judging the competitive worth of others, which never stint at distributing faults, and which are most comfortable in accepting the patronage of overly corrupt corporate leaders. In Cheran, there is a thirst for revolutionary subjectivity. There is no dismal hunger for orthodoxy, nor lofty gestures for revolution. While there is an atmosphere fraught with foreboding, there are increasing occasions for multiple points of dialogue where the inhabitants 
huddle together in discussions of new vistas of revolutionary consciousness and organization.

We cannot have market freedom, hierarchical harmony or authentic democracy within the social universe of capital - this monstrosity of monopolistic imperialist capitalism - that is unable to distribute overproduction and unable to function even minimally without the extraction of surplus value. We must not be deceived. We must reject liberal pluralism and methodological individualism, as it only serves to bolster neoliberalism and the capitalist state. Our job on the left is to cobble together strategies and tactics from the debris of human suffering that surrounds us and that can unite us in a common cause. An eco-pedagogical approach that understands the ways that human suffering is part of ecocide is a necessary part of this left strategy.

Critically, however, this will not be a socialist strategy that denies the different ontological and epistemological realities of the world's peoples, particularly subordinated classes. We must recognize that we live in 'un mundo donde muchos mundos coexistan' ('a world where many worlds coexist') and this means that we have an opportunity to resignify the notion of critical agency from the position of subaltern exteriority - that is, from the subaltern side of colonial difference in the spirit of the Zapatista dicho ('saying') of mandar obedeciendo ('to rule by following') and andar preguntando or preguntando caminamos ('walking we ask questions'), which means we make our road of liberation by walking (i.e. as we go along). This horizontal approach to organization (emphasizing interclass unity) contrasts with andar predicando or predicando caminamos ('walking I tell you'), which is a vertical form of organization where one group tells another which way to go (often described as a form of Leninist vanguardism and supraclass harmony). Of course, this is organizing from a base of affection, or what has been called política afectiva ('affective politics') or horizontalidad ('horizontalism'), where one organizes at one's own pace: 'caminamos, no corremos, porque vamos muy lejos' ('we walk, not run, because we are going very far').

My own preference is the term, '¡Que se vayan todos!' ('Out with them all!'), as I think that life against and beyond capital requires more than local struggles for selfsustainability, direct democracy and participatory democracy, as important as these struggles are. We need to figure out how to organize the totality of everyday life and, for that to occur, we must first articulate the revolutionary subject. And our struggle must not only be local, to cease creating capitalism as much as resisting capitalism; rather, it must be massively universal - stronger, in fact, than the corporations that have hijacked the state. Resistance must be as global as the worldwide threats that capitalism poses to the complexity of global ecosystems, but also as global as the transnational suffering caused by capitaist exploitation.

As more and more people now exist outside the control of the state, in vast slums and favelas throughout the world, the struggle to bring down capitalism and replace it 
with a more democratic and sustainable alternative must have a viable vision of what a social universe outside of capitalist value production will look like.

Tellingly, guerrilla fighters in Latin America, like indigenous groups worldwide, have often identified their struggle with the permanence and sanctity of nature. In Nicaragua, the vicious Reagan-backed counterrevolutionaires known as the Contras deliberately terrorized the rural communities, especially teachers, as a tactic for destroying the morale of the Sandanistas. David Craven reports that "the U.S.-backed Contras executed, got example, as many as 189 Nicaraguan school teachers in an effort to terrorize psychologically the populace of rural areas" (2002, p. 154). Craven writes of the Nicaraguan guerrillas' "belief during the insurrection that mountains had a 'mythical force' as 'our indestructibility, our guarantee of the future"' (2002, p. 148). He summarizes Carlos Fuentes's opinion that "Sandino and the Sandanistas were victorious against imperialism because their adversaries could not defeat nature, no matter how formidable the Western-backed technological edge was in military terms" (2002, p. 148).

Craven describes the significance of the volcano, Momotombo, which signified in revolutionary Nicaragua technological progress because it became the site of a geothermic electric plant which used volcanic steam to generate over 12 percent of Nicaragua's energy needs. Craven (2002, p. 149) notes: "Mountains thus came to signify national selfsufficiency in an entirely new sense.... a traditional respect for nature was combined with a modern mastery of energy sources that left the ecosystem unharmed" (a fact enirely at odds with the ecological devastation endemic to capitalist industrialization under Somoza).

Tragically, we do not share such a perspective. It has brought us a bloated Behemoth with a rictus of poisoned fangs, and fracking fluid coursing through its veins. We live in the Golgotha of the planet, in which the global coloniality between Europeans/Euro-Americans and non-Europeans is increasingly organized in a hierarchical division of labour that is nothing less than a massive form of global apartheid. Not only do we need a pedagogy that does not avert attention from contemplating problems of social, political and cultural domination, and does not obfuscate its own complicity with the coloniality of power, we need a mass struggle determined by our collective engagement with the world economy as it participates in the natural world. This will surely require new forms of radical subjectivity and agency. It is to the task of building those new forms of political and pedagogical agency that revolutionary critical eco-pedagogy must dedicate itself. Noam Chomsky (2013) pitches the challenge as follows:

In future, historians (if there are any) will look back on this curious spectacle taking shape in the early 21 st century. For the first time in human history, humans are facing the significant prospect of severe calamity as a result of their actions - actions that are battering our 
prospects of decent survival. Those historians will observe that the richest and most powerful country in history, which enjoys incomparable advantages, is leading the effort to intensify the likely disaster. Leading the effort to preserve conditions in which our immediate descendants might have a decent life are the so-called "primitive" societies: First Nations, tribal, indigenous, aboriginal. The countries with large and influential indigenous populations are well in the lead in seeking to preserve the planet. The countries that have driven indigenous populations to extinction or extreme marginalization are racing toward destruction. Thus Ecuador, with its large indigenous population, is seeking aid from the rich countries to allow it to keep its substantial oil reserves underground, where they should be. Meanwhile the U.S. and Canada are seeking to burn fossil fuels, including the extremely dangerous Canadian tar sands, and to do so as quickly and fully as possible, while they hail the wonders of a century of (largely meaningless) energy independence without a side glance at what the world might look like after this extravagant commitment to selfdestruction. This observation generalizes: Throughout the world, indigenous societies are struggling to protect what they sometimes call "the rights of nature," while the civilized and sophisticated scoff at this silliness.

Moving from an abstract universalism to a pluriversalism (see the work of Ramon Grosfoguel), from modernity to transmodernity (completing the unfinished project of decolonialism), from a vanguardismo to a retoguardismo, from an abstract utopia to a concrete utopia, from 'andar predicando' to 'andar preguntando', from a post-colonial critique to decolonial pedagogy and an appreciation for the communalidad of first nations peoples and pueblos originarlos, and from environmental education to ecopedagogy and the politics of sustainability, revolutionary critical pedagogy is positioning itself for a transnational struggle for a socialist alternative to capitalist value production. In this age where we work within an asset economy that makes profits from fictional investment markets imbued with the stench of greed while much of the world's population suffers, revolutionary critical pedagogy is poised to form transnational alliances with social movements that are working towards a vision of a social universe where labour processes are organized autonomously by the direct producers, where direct and participatory democratic administrative arrangements flourish, and where there exists a strong emphasis on social relations and human development that focus on service to others and the common good. This vision must include recognition of plural worlds, of indigenous worldviews and ways of being, as well as a shared commitment to the stewardship of the natural envirnoment.

The questions that remain point to an urgent challenge for the left: how extensive should be the uprooting of existing society and what should be the new social relations 
and new forms of social consciousness that replace current relations of exploitation and alienation?

\section{Towards a Planetary Communalidad}

Given the dire ecological situation, but also the reality that the very wealthy are insulated by their wealth and arms from immediate effects of such devastation, how can a new transformative understanding of the human place in the natural world be forged and practiced? While there is no effective indemnity against failure, we have no choice today than to move forward as concrete utopians workers who refuse to conceal our partisanship for a radically different future. We may not choose to call this future socialist. We might instead call for a form of planetary communalidad. But whatever we choose to call the future, it will require a simultaneous revolution in our relations with nature and in our social relations of production.

Mad troubadour poet and cloth-maker, Francesco di Bernardone, more commonly known as St. Francis and considered to be the patron saint of ecology, is often held in high regard by environmentalists. Yet, you don't have to be seen weeping, howling, screeching, and writing canticles to Brother Sun, dancing in your undergarments and exhorting sinners to give up their possessions to engage in ecological praxis. Nevertheless, you are required to make a pedagogical commitment to unpacking the strong metabolic relationship between human beings and society and in so doing recognize that ecological degradation and the destruction of biodiversity that is currently engulfing the planet is not only tied to economic crises but is built into the very way human beings relate to ecosystems in their wish to dominate or master them.

If St. Francis, who loved the poor and the downtrodden and who was anything but anthropocentric, could be considered the Angel of the sixth seal in Revelation (7:23 ) "ascending from the east....saying, Hurt not the earth, neither the sea, nor the trees," as some Catholics claim, then Hugo Chavez is John the Baptist, who fulminated against imperialist nations and called on them to mend their ways, while himself advocating the principle of "buen vivir," to live well. But this term, which has indigenous roots, is very different from the North American term, "the good life." Buen Vivir requires that individuals in their various communities are in actual possession of their rights and are able to exercise their responsibilities in the context of a respect for diversity and in accordance with the rights of ecosystems. It's about social wealth-not material wealth. In 2001, Chavez' congress, overseeing one of the world's most bio-diverse countries, required millions of acres of untilled land where plantation owners squatted to be sold to the landless. Missions 'Zamora', 'Arbol' and 'Agro', were set up to protect the environment, native peoples and campesinos (agricultural workers). Environmental benefits have accrued from de-urbanizing the population and reducing food 
miles. Chavez also ushered in improved land-ownership structures that resulted in improved environmental stewardship and associated gains in biodiversity and efficiency.

But we do not need to be saints to enter the struggle, to develop a communal metabolism to fight the class-based accumulation of capitalism. We can start now by engaging in acts of prefiguration, that is, by living and thinking as if we were in the future right now by promoting the idea of living well. Perhaps it is Evo Morales (2008) who says it best:

As long as we do not change the capitalist system for a system based in complementarity, solidarity and harmony between the people and nature, the measures that we adopt will be palliatives that will limited and precarious in character. For us, what has failed is the model of "living better", of unlimited development, industrialisation without frontiers, of modernity that deprecates history, of increasing accumulation of goods at the expense of others and nature. For that reason we promote the idea of Living Well, in harmony with other human beings and with our Mother Earth.

We don't have to wait until we have a perfect society, we can begin to create the alternative worlds we wish to create right at this very moment, as what we have at hand contains the lineaments of what could be. A movement towards the future exists in every breath that we take. All the acts that we take in the here and now have a prefigurative potential. What we call for is a prefigurative praxis. There are always cracks in historical time, where the light shines through. The battle for that future will be illuminated by this light. And it will be fought with fierceness. So if we must be burdened by nostalgia, let it be nostalgia for the future.

\section{Note}

[1] This is an expanded and significantly revised version of a preface written for Occupy Education by Tina Evans, Peter Lang Publishers. A version of this appeared under the title, Objection Sustained: Revolutionary Pedagogical Praxis as an Occupying Force in Policy Futures in Education, Volume 10 Number 4 2012. I want to thank Sam Fassbinder and Richard Kahn for their criticisms and suggestions as well as anonymous reviewers. I especially want to thank Elaine Coburn, whose editorial insights and recommendations have proved of inestimable value in developing this work further. 


\section{References}

Best, Steven, Richard Kahn, Peter McLaren, and Anthony J. Nocella, (eds.). (2011). The Global Industrial Complex: Systems of Domination. Lanham, MD.:Lexington Books.

Chomsky, Noam. (2013). Can Civilization Survive Capitalism? As retrieved from RSN: http://readersupportednews.org/opinion2/279-82/16453-focus-can-civilization$\underline{\text { survive-capitalism }}$

Craven, David. (2002). Art and Revolution in Latin America: 1910-1990. New Haven and London: Yale University Press.

Darder, Antonia. (2011). A Dissident Voice: Essays on Culture, Pedagogy and Power. New York: Peter Lang Publications.

Evans, Tina Lynn. (2012). Occupy Education: learning and living sustainability. New York: Peter Lang Press.

Fassbinder, Samuel, Anthony Nocella, and Richard Kahn. (2012).Greening the Academy: Ecopedagogy Through the Liberal Arts. Rotterdam: Sense Publishers.

Fassbinder, Samuel. (2008). Capitalist Discipline and Ecological Discipline. Green Theory and Praxis 4:2, pp. 87-101.

Grosfoguel, R. (2007) Descolonizando los universalismos occidentales: el pluriversalismo transmoderno decolonial desde Aimé Césaire hasta los Zapatistas, in S. CastroGomez \& R. Grosfoguel (Eds) El giro decolonial: reflexiones para una diversidad epistémica más allá del capitalismo global, pp. 63-77. Bogota: Siglo del Hombre Editores.

Grosfoguel, R. (2008) Para descolonizar os estudos de economia política e os estudos póscoloniais: transmodernidade, pensamento de fronteira e colonialidade global, Revista Crítica de Ciências Sociais , 80, 115-147.

Grosfoguel, R. 2008a - "World-System Analysis and Postcolonial Studies: A Call for Dialogue from the Coloniality of Power' Approach", in Revathi Krishnaswamy and John C. Hawley, eds., The Postcolonial and the Global. Minneapolis: 
University of Minnesota Press, pp. 94-104.

Grosfoguel, R. 2007a - "The Epistemic Decolonial Turn: Beyond Political Economy Paradigms." Cultural Studies 21(2-3):211-23.

Foster, John Bellamy. (2009). The Ecological Revolution: Making Peace with the Planet. New York: Monthly Review Press.

Freire, Paulo. (2000). Pedagogy of the Oppressed. New York and London: Continuum.

Freire, Paulo. (1985). "Dialogue is not a Chaste Event." Compiled by Paul Jurmo. The Center for International Education, School of Education. Hills House South. University of Massachusetts, Amherst.

Grande, Sandy. (2004). Red Pedagogy. Rowman \& Litterfield Publishers, Inc.

Grosfoguel, R. (2008) Para descolonizar os estudos de economia política e os estudos póscoloniais: transmodernidade, pensamento de fronteira e colonialidade global, Revista Crítica de Ciências Sociais, 80, 115-147.

Harvey, David. (2000). Spaces of Hope. University of California Press.

Hudis, Peter. (2005). Marx's Critical Appropriation and Transcendence of Hegel's Theory of Alienation. Presentation to Brecht Forum, November.

Hudis, Peter. (2010). The Critical Pedagogy of Rosa Luxemburg. Paper prepared for the Encuentro Internacional del Pensamiento Critico: Marxismo y Educacion Popular. Morelia, Michoacan, Mexico, 9-11 December, 2010.

Hudis, Peter. (2012). Marx's Concept of the Alternative to Capitalism. Brill: The Netherlands.

Jameson, Fredric. (2009). Valences of the Dialectic. London and New York: Verso.

Johnston, Josee. (2003). "Who Cares About The Commons?" Capitalism Nature Socialism 14:4 (December), 1-42. Accessed 2/26/2013 at http://individual.utoronto.ca/joseejohnston/CNS2003.pdf.

Kahn, Richard (2012). Afterword, in Tina Lynn Evans, Occupy Education: learning and living sustainability. New York: Peter Lang Press, pp. 301-310. 
Kahn, R. . (2010). Critical Pedagogy, Ecoliteracy, and Planetary Crisis: The Ecopedagogy Movement. New York: Peter Lang.

Kovel, Joel. (2007). The Enemy of Nature: The End of Capitalism or the End of the World?. London: Zed Books.

Malott, Curry. (2013). Questioning the American Dream: As Essay Review of Marsh's Class Dismissed. Education Review, volume 16, no. 3. http://www.edrev.info/essays/v16n3.pdf

Martinez-Aier, Joan. (2002). The Environmentalism of the Poor. Northampton MA: Edward Elgar Publishing.

Marx, Karl. (1967). Capital: Volume 1, trans. S. Moore and E. Aveling, ed. F. Engels, New York: International Publishers.

Marx, Karl. (1977). Capital, volume 1. Trans. Ben Fowkes. Knopf Doubleday Publishing Group. (New York: 1977).

Marx, Karl. (1977). Capital: Volume 3, trans. S. Moore and E. Aveling, ed. F. Engels, New York: International Publishers.

Martinez-Alier, Joan. 2002. The Environmentalism of the Poor: A study of ecological conflicts and valuation. Cheltenham and Northampton: Edward Elgar.

McLaren, Peter and Houston, Donna. 2004, Revolutionary Ecologies: Ecosocialism and Critical Pedagogy. Educational Studies 36 (1): 27-44

Mies, Maria, \& Shiva, Vandana. (1993). Ecofeminism. Zed Books.

Moore, J. (2011). "Ecology, Capital, and the Nature of Our Times: Accumulation and Crisis in the Capitalist World-Ecology." Journal of World-Systems Research 17(1), 108-147.

Morales, Evo. (2008). Save the Planet from Capitalism. As retrieved from Links: http://links.org.au/node/769.

Navdanya Trust (2013). Navdanya. Online. Accessed 2/26/2013. 
Ollman, Bertell. (2003). Dance of the Dialectics: Steps in Marx's Method. Urbana and Chicago: University of Illinois Press.

Robinson, William I. (2008) Latin America and Global Capitalism: a critical globalization perspective. Baltimore, MD: Johns Hopkins University Press.

Shiva, Vandana (2005). Earth Democracy: Justice, Sustainability, and Peace. Cambridge MA: South End.

Smith, Linda Tuhiwai (1999). Decolonizing Methodologies. London and New York, Zed Books, and University of Otago Press, Dunedin, New Zealand

Žižek, S. \& Milbank, J. (2009) The Monstrosity of Christ: paradox or dialectic? Cambridge, MA: MIT Press.

Žižek, S. (2012). Less Than Nothing: Hegel and the Shadow of Dialectical Materialism. London and New York: Verso.

PETER MCLAREN is the recipient of numerous awards and honours for his work in critical pedagogy, his publications translated into twenty languages. As a political activist, he lectures worldwide and works with revolutionary, community and educational groups around the globe. Peter McLaren is Professor of Urban Schooling, the Graduate School of Education and Information Studies, University of California, Los Angele and Distinguished Fellow in Critical Studies at Chapman University, California. Website: www. petermclaren.org 